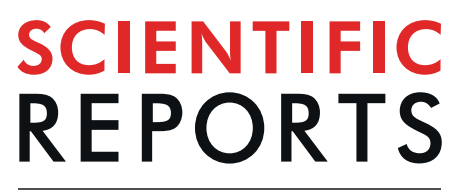

natureresearch

\title{
OPEN Blue Carbon stock in Zostera noltei meadows at Ria de Aveiro coastal lagoon (Portugal) over a decade
}

Received: 20 August 2018

Accepted: 9 September 2019

Published online: 07 October 2019

\begin{abstract}
Ana I. Sousa ${ }^{1}{ }^{1}$, José Figueiredo da Silva ${ }^{2}$, Ana Azevedo ${ }^{3}$ \& Ana I. Lillebø ${ }^{1}$
This work assessed the Blue Carbon (C) stock in the seagrass meadows (Zostera noltei) of Ria de Aveiro coastal lagoon (Portugal), and evaluated its spatio-temporal trend over the 2003-2005 to 2013-2014 period. Zostera noltei spatial distribution, restricted to intertidal areas in 2014, was mapped by remote sensing using an unmanned aerial vehicle (UAV) and aerial photography. Zostera noltei biomass was also monitored in situ over a year and its Blue $C$ stock was estimated. By 2014, intertidal meadows covered an area of $226 \pm 4$ ha and their Blue C stock ranged from $227 \pm 6$ to $453 \pm 13 \mathrm{Mg}$ C. Overall, Ria de Aveiro Z. noltei intertidal meadows increased in extent over the 2003-2005 to 2013-2014 period, corroborating the recent declining trend reversal observed in Europe and contrary to the global decline trend. This spatio-temporal shift might be related to a natural adjustment of the intertidal meadows to past human intervention in Ria de Aveiro, namely large-scale dredging activities, particularly in the 1996-1998 period, combined with the more accurate assessment performed in 2014 using the UAV. This recovery contributes to the effective increase of the Blue C stock in Ria de Aveiro and, ultimately, to supporting climate regulation and improving ecosystem health. However, major dredging activities are foreseen in the system's management plan, which can again endanger the recovery trend of $Z$. noltei intertidal meadows in Ria de Aveiro.
\end{abstract}

In coastal ecosystems, Blue Carbon (C) corresponds mostly to the $\mathrm{C}$ stored in the soil, living biomass (aboveground and belowground), and non-living biomass (e.g. litter) of seagrass meadows, salt marshes, and mangroves ${ }^{1}$. Seagrass meadows play a major role as Blue $\mathrm{C}$ sinks, given their ability to sequester large quantities of $\mathrm{C}$ in biomass and, more importantly, in the rhizosphere ${ }^{2-5}$, therefore being more efficient $\mathrm{C}$ sinks than most terrestrial forests ${ }^{1}$. Seagrass meadows can remove large amounts of atmospheric greenhouse gases such as carbon dioxide $\left(\mathrm{CO}_{2}\right)^{6,7}$, one of the major concerns worldwide. Seagrass meadows also increase sediment trapping, vertical accretion, and plant debris accumulation resulting in increased $\mathrm{C}$ storage in the sediment ${ }^{1,8}$. While $\mathrm{C}$ is stored for years to decades in plant biomass ${ }^{1}$, it can be stored in the sediment for millennia ${ }^{9,10}$. These high rates of $\mathrm{C}$ sequestration and accumulation lead to a large $\mathrm{C}$ stock in coastal wetlands and confirm their relevance for climate regulation and climate change mitigation ${ }^{11,12}$, highlighting the need of preserving these habitats. Furthermore, seagrasses are important habitats in the scope of the European Union (EU) Habitats Directive, and valuable indicators of the quality of the marine environment, therefore acknowledged as biological quality elements in the scope of the Water Framework Directive (WFD) and Marine Strategy Framework Directive (MSFD). International conventions such as the Convention for the Protection of the Marine Environment of the North-East Atlantic ("OSPAR Convention"), Helsinki Convention on the Protection of the Marine Environment of the Baltic Sea Area (HELCOM), Barcelona Convention for the Protection of the Mediterranean Sea, and Ramsar Convention on Wetlands, also highlight the need to preserve seagrass meadows. These conventions and regulations are particularly important in a scenario of global seagrass decline, which determines the conservation of these coastal wetlands as critical to assure the $C$ sink capacity of these habitats and their intrinsic ecosystem services (e.g. climate regulation, stabilisation and erosion control, maintenance of nursery populations and habitats). 
Despite the environmental and socio-economic importance of seagrass ecological services, these habitats are strongly declining worldwide ${ }^{13,14}$. Natural and anthropogenic drivers have led to coastal wetlands degradation $^{14}$ and sediment-stored C release to the atmosphere and ocean, shifting these ecosystems from C sinks to C sources $^{14-16}$. Some of the main triggers for wetland loss are sediment erosion and physical impacts (e.g. dredging and lugworm burial of seeds and seedlings) ${ }^{12,17,18}$. Herbivores and bioturbators (in high densities) also reduce C storage by increasing microbial mineralization ${ }^{19}$, as well as increasing erosion and re-suspension due to burrowing activities ${ }^{20-22}$. Other anthropogenic pressures include high nutrient loading, sediment contamination, habitat disruption, invasive species, land reclamation, and intense fishing activities ${ }^{13,23-26}$.

Ria de Aveiro, a coastal lagoon in Portugal, is a long-term ecological research (LTER) site (http://www. lter-europe.net/) with several important habitats that justify its inclusion in the Natura 2000 network and classification as a Special Protection Area, comprising areas classified as Sites of Community Importance. Similar to the loss and habitat fragmentation processes observed for seagrass meadows worldwide, those in Ria de Aveiro have declined since the 1980's to mid 2000's, mostly through the loss of biodiversity (i.e. loss of Zostera marina Linnaeus, 1753, Stuckenia pectinata (L.) Börner, 1912, and Ruppia cirrhosa (Petagna) Grande, 1918), the loss of subtidal Zostera noltei Hornemann, 1832 meadows and reduction of its intertidal meadows ${ }^{27,28}$. The main causes for seagrass decline in Ria de Aveiro were changes in the lagoon hydrodynamics ${ }^{29-31}$, particularly those resulting from harbour related activities (main driving forces) ${ }^{29}$. These activities resulted in the increase of hydromorphological pressures in the lagoon due to dredging of navigable channels, and in changes of hydrodynamic features, such as increased tidal amplitude and current velocity ${ }^{30-33}$. Fishing activities involving motor boating and bait digging in tidal flats ${ }^{34}$ have also been mentioned as pressures because sediment remobilization negatively affects seagrass stability.

Taking into account the importance of seagrass meadows as Blue $C$ sinks, the current work aimed to: 1) assess the current areal extent and distribution of $Z$. noltei meadows at Ria de Aveiro; 2) compare the areal extent and distribution of $Z$. noltei meadows in 2005 and 2014; and 3) estimate the Blue C stock addressing its trend over a decade. Thus, the following null hypotheses were addressed and tested: 1) over the last decade, the spatial extent of seagrass meadows at Ria de Aveiro did not increased or declined, therefore contradicting the global decline trend; and 2) the Blue C stock at Ria de Aveiro Zostera noltei meadows in 2014 was not higher than a decade before. To test the outlined hypotheses and address the abovementioned aims, Z. noltei areal extent at Ria de Aveiro was assessed and mapped using aerial photography (and an unmanned aerial vehicle) and ground-truth validation; $Z$. noltei biomass and $C$ pools were monitored and quantified monthly, and the Blue C stock was estimated for seagrass meadows.

\section{Materials and Methods}

Study site. Ria de Aveiro is a temperate, shallow, well-mixed coastal lagoon located on the western coast of Portugal $\left(40^{\circ} 38^{\prime} \mathrm{N}, 8^{\circ} 44^{\prime} \mathrm{W}\right)$. Its complex geometry includes several branches, inner basins, mudflats, and islands forming four main channels (Mira, Ovar, Espinheiro, and Ílhavo) (Fig. 1). Ria de Aveiro is a mesotidal lagoon, where an engineered inlet channel provides a permanent connection to the Atlantic Ocean, and its semidiurnal tides are the main driver of water circulation within the system.

Before 1990, subtidal and intertidal seagrasses had a massive ecological, economic, and social role in Ria de Aveiro region. Back then, a mixture of seagrasses and macroalgae ("moliço"), was intensively harvested and used as fertilizer in agricultural field ${ }^{35}$. The commercial harvesting of seagrasses ended about 20 years ago (1998), after a remarkable decrease in the subtidal populations of Zostera spp. ${ }^{32}$. Azevedo et al.$^{27}$ summarized the available seagrass data for Ria de Aveiro, describing a decrease in coverage in the last decades ${ }^{31,32}$, and mentioning that by 2008 and 2010, in Mira and Ovar channels ${ }^{28}$, respectively, Zostera noltei (dwarf eelgrass) was restricted to intertidal areas. Nevertheless, these studies focused on confined seagrass meadows within Ria de Aveiro.

Mapping of seagrass meadows. To map Z. noltei meadows and assess their recent temporal and spatial changes in Ria de Aveiro, aerial photographs were obtained during low tide at selected areas in November 2013 and March 2014 (Fig. 1). These areas were selected for representing the most extensive/larger meadows in 2013-2014 that were also photographed in 2003-2005, and were assessed using an unmanned aerial vehicle (UAV), AscTec Falcon Octocopter, with an RGB camera attached (Sony NEX-5N) equipped with 24-mm lens. For image acquisition, a higher resolution approach was used along the Mira channel (Fig. 1 - areas A, B, C1 and $\mathrm{C} 2$ ). Here, the flights were performed following a predefined path and pattern and the camera was operated at $150-180 \mathrm{~m}$ altitude, vertical to the pre-selected points $\left(90^{\circ}\right.$ angle). Pixel resolution ranged from $3.8 \pm 0.3$ to $4.1 \pm 0.1 \mathrm{~cm}$. At additional locations (Fig. 1 - areas D to P), lower resolution images were taken at $25-35^{\circ}$ of the selected points, from fixed points/locations and capturing panoramic images, at about $200 \mathrm{~m}$ altitude. In these areas, pixel resolution ranged from $4.4 \pm 0.0$ to $5.3 \pm 0.1 \mathrm{~cm}$. Based on the pixel resolution, the standard deviation (for each area) and error propagation (for the total area) associated with meadows' extent estimation were calculated. For both approaches, acquired images were geo-referenced, and combined via a process of image ortho-rectification, mosaicking, and transferring to raster images using the Agisoft PhotoScan ${ }^{\odot}$ software. The aerial photograph mosaic was then imported to a geographical information system (GIS) using ArcMap (ArcGIS 10 ), and the boundaries of seagrass meadows were drawn on the map (polygons). The mapped seagrass meadows refer to the external boundaries of the meadows where seagrass relative coverage was up to $100 \%$ including some fragmented areas. The areal extent of seagrass meadows (ha) was calculated using ArcGIS. The interpretation of the aerial images recorded in 2013-2014 was validated by ground-truth surveys of the external limits of several of the mapped Zostera meadows performed immediately after the UAV flights. These surveys were carried at low tide using a GPS receiver while walking over the external limit of the areas where Z. noltei cover was very high ( $>75 \%$, visual estimation). Data from further field surveys, including local identification of the $Z$. noltei meadows and local photographs, were also included in this validation process. 


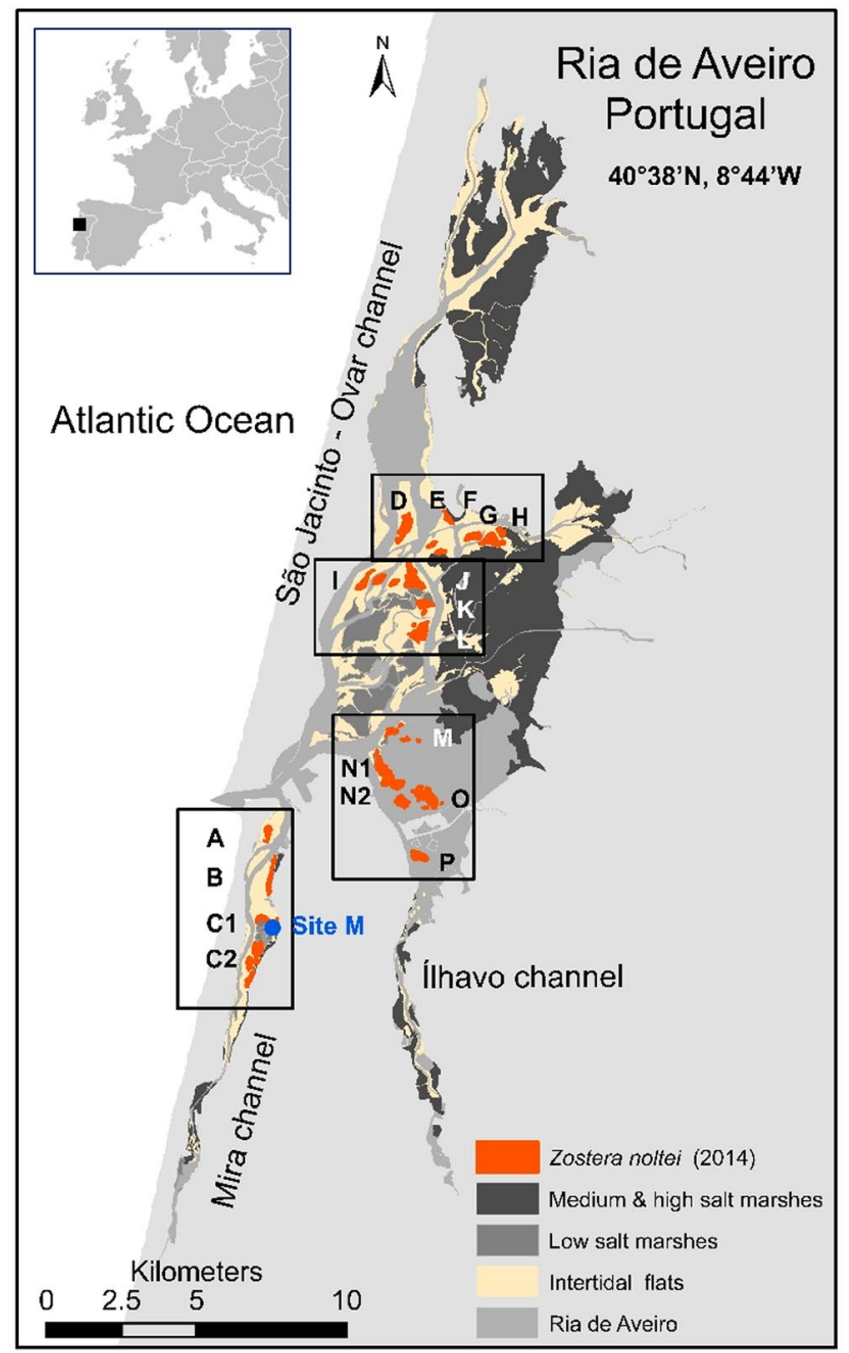

Figure 1. Ria de Aveiro (Portugal) map showing the spatial distribution of salt marshes, seagrass meadows (Zostera noltei) and intertidal mudflats. Sampling site for biomass and C stock monitoring at Mira channel (Site M) is indicated as a blue circle. The 18 areas surveyed for Zostera noltei spatial distribution and wherein aerial images were acquired are indicated within boxes (A to P). Map generated with ArcGIS 10 (http://www.esri.com/software/arcgis).

For the 2003-2005 surveys, aerial images were obtained from a light aircraft, flying at 700-1000 m altitude, several times per year, during low tide. Photographs were taken from the plane using a camera loaded with a 100 ASA colour film and equipped with a 50-mm lens. The images obtained had a tilt angle of up to $35^{\circ}$ and their resolutions ranged from $1 \mathrm{~m}$ to over $3 \mathrm{~m}$. The visual interpretation of these photographs and the data obtained from ground-truth surveys (performed from 2003 to 2005) were used to validate the seagrass meadows' boundaries with a $9 \mathrm{~m}$ maximum error, by drawing polygons on the map using ArcMap (ArcGIS 10). Following this procedure, the areal extent of seagrass meadows was computed and estimated with an error ranging from 12.2 to $27.5 \%$, depending on the meadow shape (perimeter dimension).

The developed maps for the 2003-2005 and 2013-2014 periods were compared concerning spatial location, extent (area), and temporal or spatial shift. Using ArcGIS, an intersection procedure was performed and the areas that overlapped in time, the new vegetated areas, and the lost meadow areas were identified and mapped. The rates of change (\%) for each surveyed area were calculated as described in Waycott et al. ${ }^{14}$. Thus, the trajectory of the change, $\mu\left(\% \mathrm{yr}^{-1}\right) \mathrm{was}$ calculated over time $(t)$ considering the initial to final surveyed areas (A0 and At, respectively) as $\mu=[\ln (\mathrm{At} / \mathrm{Ao}) / \mathrm{t}]^{*} 100$. It must be mentioned that technological advances allowed more accurate areal extent estimates in the 2013-2014 assessment than in the 2003-2005 assessment, wherein a larger error was associated with seagrass meadows' mapping. Nevertheless, the approach used in the present work is relevant in itself, as it addresses the challenge and overcomes the limitations of combining the best available historical data with recent data to study ecological trends. Moreover, this study is the first assessment of seagrasses spatial distribution and extent in the entire Ria de Aveiro lagoon.

Sampling strategy: Zostera noltei biomass monitoring and $\mathrm{C}$ pool. Zostera noltei biomass was sampled monthly from a well-established meadow at Mira channel (Fig. 1; 40³6 $21.57^{\prime \prime} \mathrm{N}, 8^{\circ} 44^{\prime} 15.28^{\prime \prime} \mathrm{W}$ ), for one year (2012-2013) during low tide. At this site, vertical photographs were taken monthly and Z. noltei cover was visually assessed, always corresponding to $100 \%$ cover. Core-liners were used to sample plant biomass 
$\left(\varnothing=15 \mathrm{~cm}\right.$, area $=177 \mathrm{~cm}^{2}$, depth $\left.=12 \mathrm{~cm} ; \mathrm{N}=5\right)$ and sediment $(\varnothing=5 \mathrm{~cm}$, depth $=12 \mathrm{~cm} ; \mathrm{N}=5)$, and these samples were immediately taken to the laboratory. Here, $Z$. noltei roots and rhizomes were carefully separated from the sediment, rinsed with distilled water, and then dried at $60^{\circ} \mathrm{C}$ until constant weight (dry weight, DW). Shoots were subject to the same procedure. Zostera noltei epiphytes were not removed as they corresponded to a negligible amount of microalgae. Biomass $\left(\mathrm{g} \mathrm{DW} \mathrm{m}^{-2}\right.$ ) was assessed for shoots (aboveground biomass), and for roots and rhizomes (belowground), separately; shoot density (shoots $\mathrm{m}^{-2}$ ) was also quantified. The aboveground and belowground $Z$. noltei biomasses were then ground and homogenised for subsequent analyses.

The top $10 \mathrm{~cm}$ sediment layer was air dried, grounded, sieved through a $0.25 \mathrm{~mm}$ mesh, and then characterized for total C content. Total $\mathrm{C}$ content in the sediment and $Z$. noltei biomasses were quantified $(\mathrm{N}=3)$ in a $\mathrm{CHN}$ analyser (Thermo Scientific, Flash2000 Organic Elemental Analyzer, connected to a Thermo Scientific, Delta V Advantage, Isotope Ratio Mass Spectrometer). Correction for inorganic C content in the sediment $\left(\mathrm{C}_{\text {inorg }}\right)$ was performed through an acidification protocol, as described in Howard et al. ${ }^{36}$. Carbonates (calcium carbonate) were removed through acidification of the sediment $(\mathrm{HCl} 1 \mathrm{~N})$, which was then gently washed with Milli-Q water, centrifuged, and re-dried at $60^{\circ} \mathrm{C}$. The mass of carbonates in the sediment was then assessed as the mass difference of pre-acidified and acidified sediment, and a correction for the contribution of $\mathrm{C}(12 \%)$ to carbonates was finally performed. The sediment $\mathrm{C}_{\text {inorg }}$ content was assessed and subtracted from the total $\mathrm{C}$ content, to estimate the organic $\mathrm{C}$ content $\left(\mathrm{C}_{\text {org }}\right)$ in the sediment ${ }^{36}$. The acidification method for the removal of $\mathrm{C}_{\text {inorg }}$ may remove part of the $\mathrm{C}_{\text {org }}$, which may lead to the overestimation of $\mathrm{C}_{\text {inorg }}$ and underestimation of $\mathrm{C}_{\text {org }}$ in the sediment ${ }^{37}$. For the Blue $\mathrm{C}$ stock assessment, only the $\mathrm{C}_{\text {org }}$ was considered. Zostera noltei $\mathrm{C}_{\text {org }}$ pool or stock $\left(\mathrm{g} \mathrm{C} \mathrm{m}^{-2}\right)$ was estimated by multiplying biomass $\left(\mathrm{g} \mathrm{DW} \mathrm{m}^{-2}\right.$ ) per $\mathrm{C}$ content $\left(\% \mathrm{DW}\right.$, or $\left.\mathrm{mg} \mathrm{g}^{-1}\right)$, while sediment $\mathrm{C}_{\text {org }}$ stock $\left(\mathrm{g} \mathrm{C} \mathrm{m}^{-2}\right)$ was calculated by multiplying the $\mathrm{C}_{\text {org }}$ content (\%) per sediment dry bulk density $\left(\mathrm{g} \mathrm{DW} \mathrm{cm}^{-3}\right)$, considering the volume over a sediment depth of $10 \mathrm{~cm}$. Dry bulk density was assessed at the same site (M) in February and June 2013 (data also included in Sousa et al. ${ }^{38}$ ). The mean dry bulk density was then used for calculations. The term $\mathrm{C}_{\text {org }}$ stock refers to the amount of $\mathrm{C}_{\text {org }}$ present at a certain time in a certain area $\left(\mathrm{g} \mathrm{C} \mathrm{m}^{-2}\right)$ over a particular sediment depth. Total $\mathrm{C}_{\text {org }}$ stock in $Z$. noltei meadows was calculated integrating both $Z$. noltei aboveground $\mathrm{C}_{\text {org }}$ stock and sediment $\mathrm{C}_{\text {org }}$ stock. The $\mathrm{C}_{\text {org }}$ stock of $Z$. noltei belowground biomass was not included in this calculation because the sediment $\mathrm{C}_{\text {org }}$ stock already includes the $\mathrm{C}_{\text {org }}$ of roots and rhizomes. The annual mean $\mathrm{C}_{\text {org }}$ stock was then used to estimate the total $C_{\text {org }}$ stock of seagrass meadows in each mapped area and of all seagrass meadows in the entire Ria de Aveiro system (spatial extent).

To determine the uncertainty of the total $\mathrm{C}_{\text {org }}$ stock for each assigned seagrass area $(f)$, the associated error propagation $(\sigma f)$ was computed assuming that $f$ depends on "area (value)" $(x)$ and "total $\mathrm{C}_{\text {org }}$ stock" $(y)$ and on their associated standard deviations represented by $\sigma_{x}$ and $\sigma_{y}$, respectively, according to the following equation:

$$
\sigma f=\sqrt{y^{2} \sigma_{x}^{2}+x^{2} \sigma_{y}^{2}}
$$

Total $\mathrm{C}_{\text {org }}$ stock was extrapolated for all Ria de Aveiro meadows, whose original data (biomass and sediment $\mathrm{C}_{\text {org }}$ ) corresponded to well-established meadows ( $100 \%$ cover). Therefore, total $\mathrm{C}_{\text {org }}$ stock corresponds to the maximum total $\mathrm{C}_{\text {org }}$ stock if all meadows present $100 \%$ cover. Because this is not the most probable scenario in all meadows, either due to new colonised areas (likely to have a lower $\mathrm{C}_{\text {org }}$ stock) or to habitat fragmentation (reducing the \% cover), the $\mathrm{C}_{\text {org }}$ stock for a potential cover of $50 \%$ was estimated. These total $\mathrm{C}_{\text {org }}$ stock estimates (considering two different $\%$ cover) provide a range for the $\mathrm{C}_{\text {org }}$ stock in the Ria de Aveiro meadows. Although this is a limitation of our estimation method, we assumed that the $\mathrm{C}_{\text {org }}$ stock was proportional to the seagrass $\%$ cover. For the 2005 assessment, the $C_{\text {org }}$ stock was estimated considering the $C_{\text {org }}$ data obtained for 2013/2014, considering, as this was the best available information, that the $\mathrm{C}_{\text {org }}$ stock was similar across healthy meadows.

\section{Results}

Seagrass meadows areal extent at Ria de Aveiro: changes over a decade. Considering the surveyed areas, the $Z$. noltei meadows total area in 2014 was about $226 \pm 4$ ha (mean \pm error propagation) (Figs $2-4$ ). In Mira channel, the areal extent of $Z$. noltei meadows was $40 \pm 3$ ha (Fig. 2, areas A to C2), in the central north area of Ria de Aveiro it was $120 \pm 1$ ha (Fig. 3, areas D to L), and in the central south area and Ílhavo channel it was 67 ha (Fig. 4, areas M to P).

Regarding the areas surveyed in 2013-2014 and in 2003-2005 (A, B, C1, C2, D, F, G, J, L, N1, and P), there was an 1.3-fold increase in the total area of seagrass meadows from 106 to $136 \pm 3$ ha (mean \pm error propagation) (Fig. 5). The surveyed areas showed a general increase in extent, except areas D, F, and J where Z. noltei area remained almost stable over time. The surveyed areas in Mira channel increased about $1.4 \pm 0.4$-fold, from 32 to $40 \mathrm{ha}$, thus corresponding to a change rate of $2.4 \% \mathrm{yr}^{-1}$. In the central north area of Ria de Aveiro, there was a $1.1 \pm 0.2$-fold increase, corresponding to a change rate of $2.4 \% \mathrm{yr}^{-1}$ (except in area $\mathrm{G}$, where a 4.2 -fold increase of the Z. noltei area, from 66 to 81 ha, was registered. In the central south area and Illhavo channel there was a $2.1 \pm 0.9$-fold increase corresponding to a change rate of $8.0 \% \mathrm{yr}^{-1}$ (from 8 to 16 ha) (Fig. 5). Overall, the highest increase in Z. noltei distribution occurred in areas A, G, and P, all geographically distant. Area Q, located in the north region of Ovar channel and surveyed in 2003-2005 only, had a Z. noltei cover area of 16 ha.

The location of $Z$. noltei meadows did not shift over time (2003-2005 vs. 2013-2014) in most of the surveyed areas, and $87 \pm 12 \%$ of the meadows surveyed in 2003-2005 were still present in 2013-2014. The spatial shift of $13 \pm 11 \%$ at the surveyed areas corresponded to meadows that were lost or to newly meadows. In Mira channel, about $89 \pm 9 \%$ (min. 81\%, max. 99\%) of the meadows recorded in 2003-2005 were also recorded in 2013-2014, being constant over time; $81 \pm 15 \%$ (min. $62 \%$, max. 99\%) of the meadows at the central north region and $96 \pm 2 \%$ (min. 95\%, max. 97\%) at the central south and Îlhavo channel were stable (Fig. 5). Globally, the newly colonised and lost meadow areas were small, ranging from 0 to $38 \%$ of the surveyed seagrass area. Most of the meadows with a lower increased coverage showed a higher spatial shift over time (B, C2, D, and J but not C1, L, and N1), 


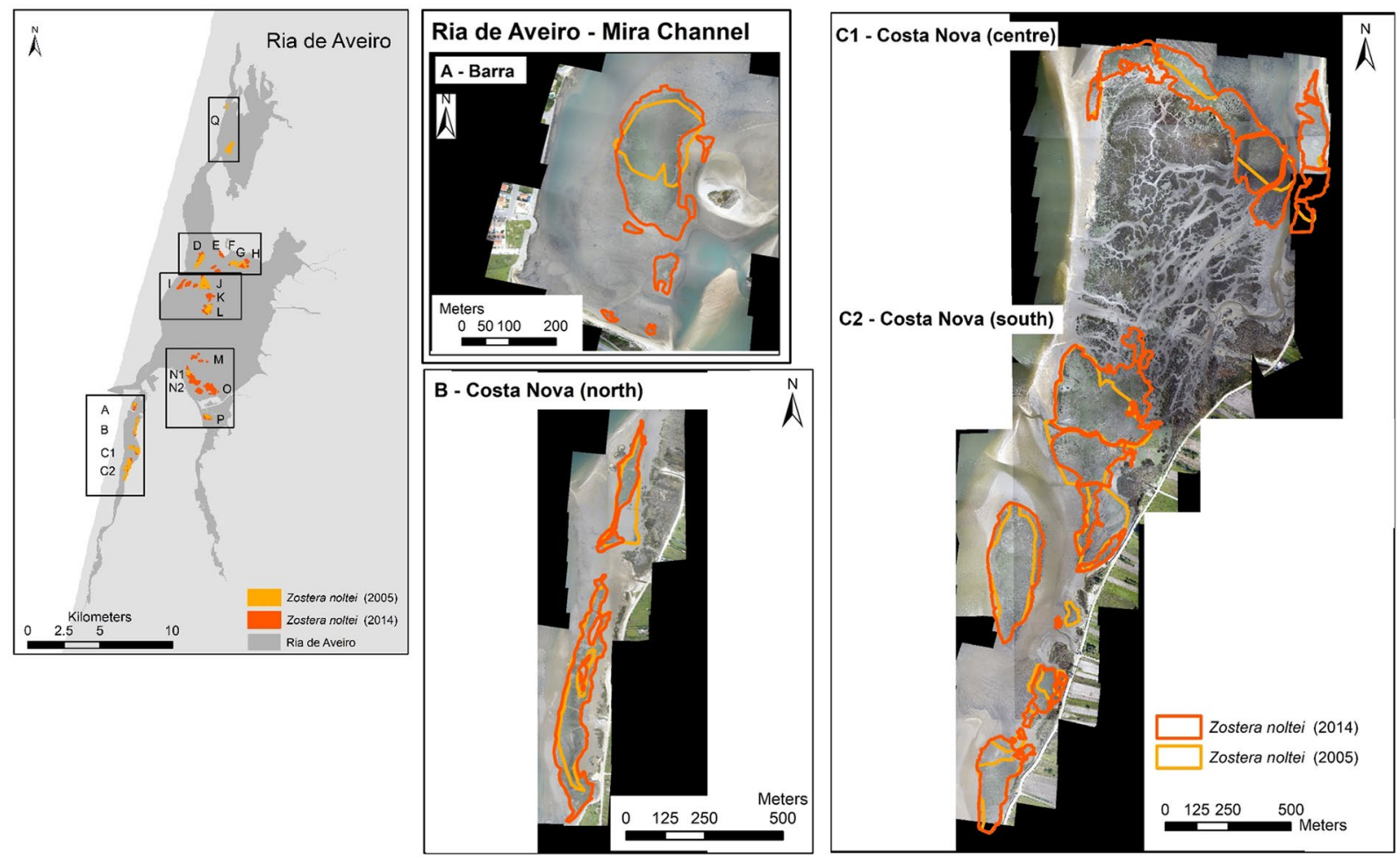

Figure 2. Zostera noltei spatial distribution at Ria de Aveiro in 2003-2005 (light orange) and in 2013/2014 (dark orange/red). Letters A to Q correspond to the areas surveyed and mapped in 2003-2005 and/or 2014. Boxes aside the map show the aerial images acquired (UAV) at each area and the seagrass distribution and extent at each survey date. Areas A to C2 were mapped both in 2003-2005 and 2014. Map generated with ArcGIS 10 (http://www.esri.com/software/arcgis). Aerial photograph mosaic performed using Agisoft PhotoScan (https://www.agisoft.com/).

corresponding to newly colonised and/or lost meadows. Moreover, areas with a higher increase in areal extent showed a reduced spatial shift $(\mathrm{A}, \mathrm{F}, \mathrm{G}$, and $\mathrm{P})$, corresponding to newly colonised areas. However, it must be taken into account that the mapping methods and accuracy were different between the surveys (2003-2005 and 2013-2014).

Zostera noltei monitoring and characterization. Zostera noltei total biomass (including shoots, roots, and rhizomes) reached maximum values in spring (April: $202.8 \pm 55.6 \mathrm{~g} \mathrm{DW} \mathrm{m}^{-2}$; May: 203.6 $\pm 79.9 \mathrm{~g} \mathrm{DW}$ $\mathrm{m}^{-2}$ ) and minimum values in winter (January: $124.3 \pm 26.7 \mathrm{~g} \mathrm{DW} \mathrm{m}^{-2}$ ) (Fig. 6). Annual mean total biomass was $168.6 \pm 25.4 \mathrm{~g} \mathrm{DW} \mathrm{m}^{-2}$. November was the exception, as aboveground seagrass biomass (shoots) was either higher than or similar to belowground biomass. The annual mean shoot density was $9567 \pm 4178$ shoots $\mathrm{m}^{-2}$, ranging from $2926 \pm 649$ in November to $17170 \pm 2160$ in April.

Zostera noltei $\mathrm{C}$ content was slightly higher in the shoots than in the roots and rhizomes, ranging from $37.0 \pm 1.0 \%$ and $33.5 \pm 0.9$ in August to $40.2 \pm 0.4 \%$ and $36.7 \pm 0.8 \%$ in April, respectively (Fig. S1, supplementary material). Carbon content in the $Z$. noltei sediment showed the lowest value in August $(1.7 \pm 0.3)$ and the highest in March (2.1 \pm 0.2$)$.

Blue $C$ pool in Z. noltei meadows. The Z. noltei $\mathrm{C}_{\text {org }}$ pool (vegetal material, seagrass) reached the maximum of $75 \mathrm{~g} \mathrm{C} \mathrm{m}^{-2}$ in May (spring) while the minimum value of $46.4 \mathrm{~g} \mathrm{C} \mathrm{m}^{-2}$ was recorded in January (winter). The annual mean $Z$. noltei $\mathrm{C}_{\text {org }}$ pool was $62.7 \pm 10.1 \mathrm{~g} \mathrm{C} \mathrm{m}^{-2}$, with shoots (aboveground biomass) contributing $37.6 \pm 8.8 \mathrm{~g} \mathrm{C} \mathrm{m}^{-2}$ and roots and rhizomes (belowground biomass) $25.1 \pm 5.4 \mathrm{~g} \mathrm{C} \mathrm{m}^{-2}$ (Table 1). For the sediment, mean dry bulk density was $1.03 \pm 0.21 \mathrm{~g} \mathrm{~cm}^{-3}$, total $\mathrm{C}$ content ranged from $1.66 \pm 0.28$ to $2.08 \pm 0.23 \% \mathrm{DW}, \mathrm{C}_{\text {org }}$ ranged from $1.44 \pm 0.08$ to $1.84 \pm 0.06 \% \mathrm{DW}$, and $\mathrm{C}_{\text {inorg }}$ ranged from $0.19 \pm 0.05$ to $0.33 \pm 0.06 \% \mathrm{DW}$ (Fig. S1, supplementary material). The annual mean $\mathrm{C}_{\text {org }}$ pool at the top $10-\mathrm{cm}$ sediment was $162.8 \pm 10.9 \mathrm{~g} \mathrm{C} \mathrm{m}^{-2}$ and ranged from $147.3 \pm 8.7 \mathrm{~g} \mathrm{C} \mathrm{m}^{-2}$, recorded in November, to $189.0 \pm 6.2 \mathrm{~g} \mathrm{C} \mathrm{m}^{-2}$ recorded in March. The total $\mathrm{C}_{\text {org }}$ pool (including $Z$. noltei biomass and sediment) annual mean was $200.3 \pm 15.8 \mathrm{~g} \mathrm{C} \mathrm{m}^{-2}$.

Considering the total $C_{\text {org }}$ pool (seagrass and sediment) per unit area and $Z$. noltei spatial extent, a maximum total $C_{\text {org }}$ stock of $453.2 \pm 12.7 \mathrm{Mg} \mathrm{C}$ (mean \pm error propagation) was estimated for Ria de Aveiro seagrass meadows in 2014 (considering the hypothetical situation of $100 \%$ cover at all meadows), while the maximum total $\mathrm{C}_{\text {org }}$ stock in 2005 was estimated as $243 \mathrm{Mg} \mathrm{C}$ (assuming a 100\% cover). Of the total $453 \mathrm{Mg}$ C estimated for 2014, $80 \mathrm{Mg}$ C were stored in the Mira channel meadows, $240 \mathrm{Mg} \mathrm{C}$ in the central north area, and $134 \mathrm{Mg} \mathrm{C}$ in the central south area and Ílhavo channel (Fig. 7). 

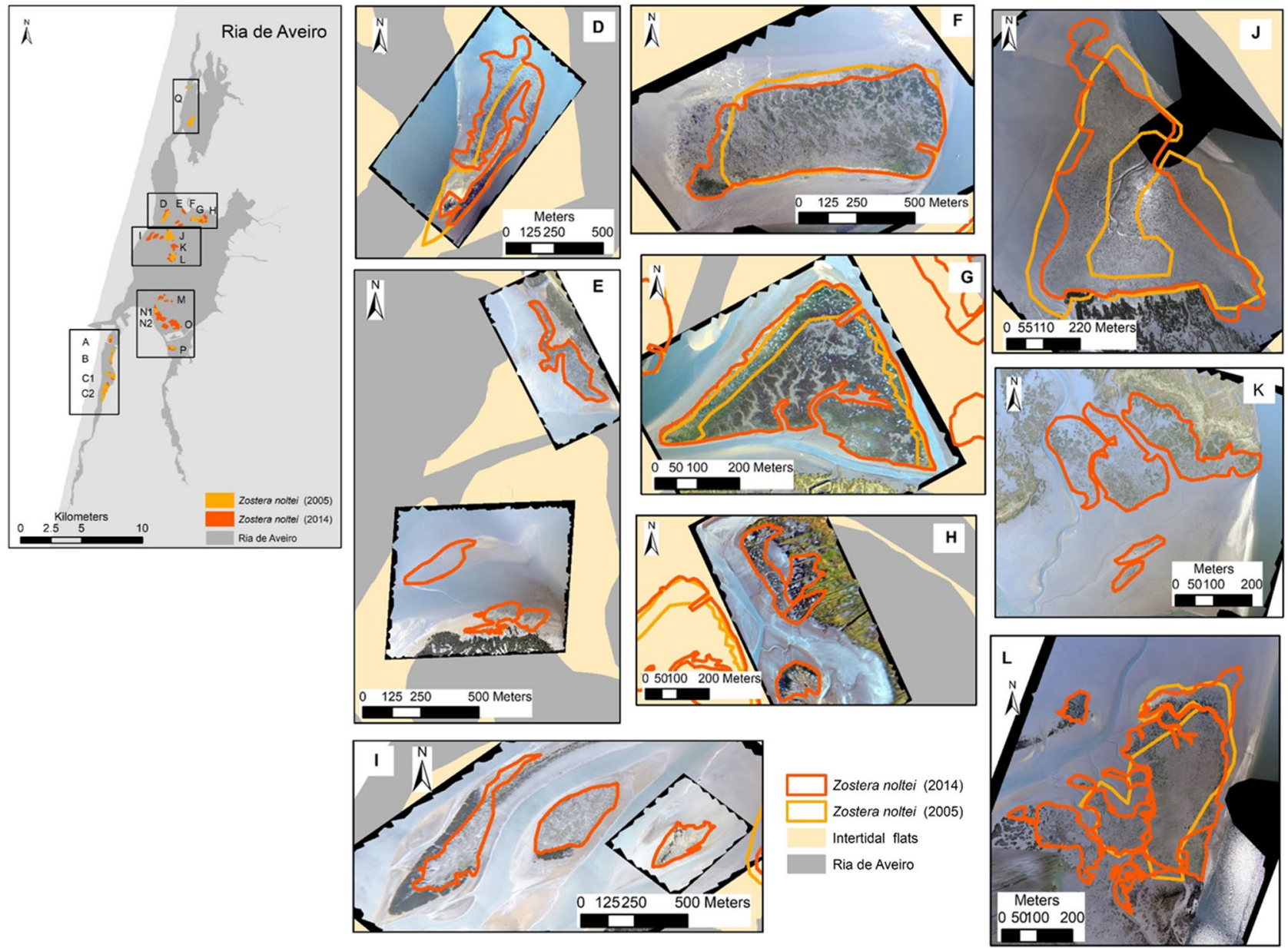

Figure 3. Zostera noltei spatial distribution at Ria de Aveiro in 2003-2005 (light orange) and in 2013/2014 (dark orange/red). Boxes aside the map show the aerial images acquired (UAV) at each area and the seagrass distribution and extent at each survey date. Areas D, F, G, J, L correspond to areas surveyed and mapped both in 2003-2005 and 2014; E, H, I, K were mapped only in 2014. Map generated with ArcGIS 10 (http://www.esri.com/ software/arcgis). Aerial photograph mosaic performed using Agisoft PhotoScan (https://www.agisoft.com/).

\section{Discussion}

The spatial extent of $Z$. noltei in the surveyed areas of Ria de Aveiro was $226 \pm 4.1$ ha in 2014 . About $60 \%$ of the seagrass areas were surveyed in both periods (2003-2005 and 2013-2014), and thus we were able to assess and discuss the spatio-temporal evolution of $Z$. noltei meadows at Ria de Aveiro. Over the studied decade, the Z nolte $i$ meadows in the surveyed areas recovered, presenting an increase in their spatial extent, from 106 to $136 \mathrm{ha}$, and there was a global reduced spatial shift in the surveyed meadows (mean $13 \pm 11 \%$ ). Most of the meadows showing a higher increase in their areal extents showed a low spatial shift, indicating that the $Z$. noltei meadows in Ria de Aveiro are stable, which has great ecological relevance, and is reflected in the Blue C stock of these meadows. Nevertheless, when interpreting these spatio-temporal changes one must have in mind that the mapping methods used in the two survey periods (2003-2005 and 2013-2014) were different, meaning that the associated uncertainty was higher in 2003-2005 maps than in 2013-2014 maps. Image resolution was much higher in 2013-2014, increasing the accuracy of the seagrass meadows maps obtained for this period. In addition, polygons defined for seagrass mapping were much more detailed in 2013-2014 than in the previous period due to the high resolution of the 2013-2014 images. The recorded increase in extent and spatial shift trend of Z. noltei at Ria de Aveiro over the analysed decade can be due to an effective increase in the meadows extent and/or to an improvement in mapping accuracy through the increase in images' resolution.

The changes in seagrass meadows at Ria de Aveiro from the 1950's to 2014 summarized in Fig. 8 were based on our results and on previously published data. Considering the entire Ria de Aveiro system, there was an apparent decrease in seagrass meadows extent from 300 ha in $2002-2004$, recorded by Silva et al. ${ }^{31}$, to 226 ha in 2014 , as obtained in the present study. However, it must be mentioned that Silva et al. ${ }^{31}$ data included macroalgae areas adjacent to Z. noltei, and not only $Z$. noltei as performed in the 2014 survey. Seagrass meadows located at the Ovar channel were accounted for by Silva et al. ${ }^{31}$, but this channel was only partially surveyed in 2014 , as area $Q$ was excluded. Therefore, seagrass meadows spatial evolution must be analysed and discussed on comparable areas, as presented at the beginning of this section. 

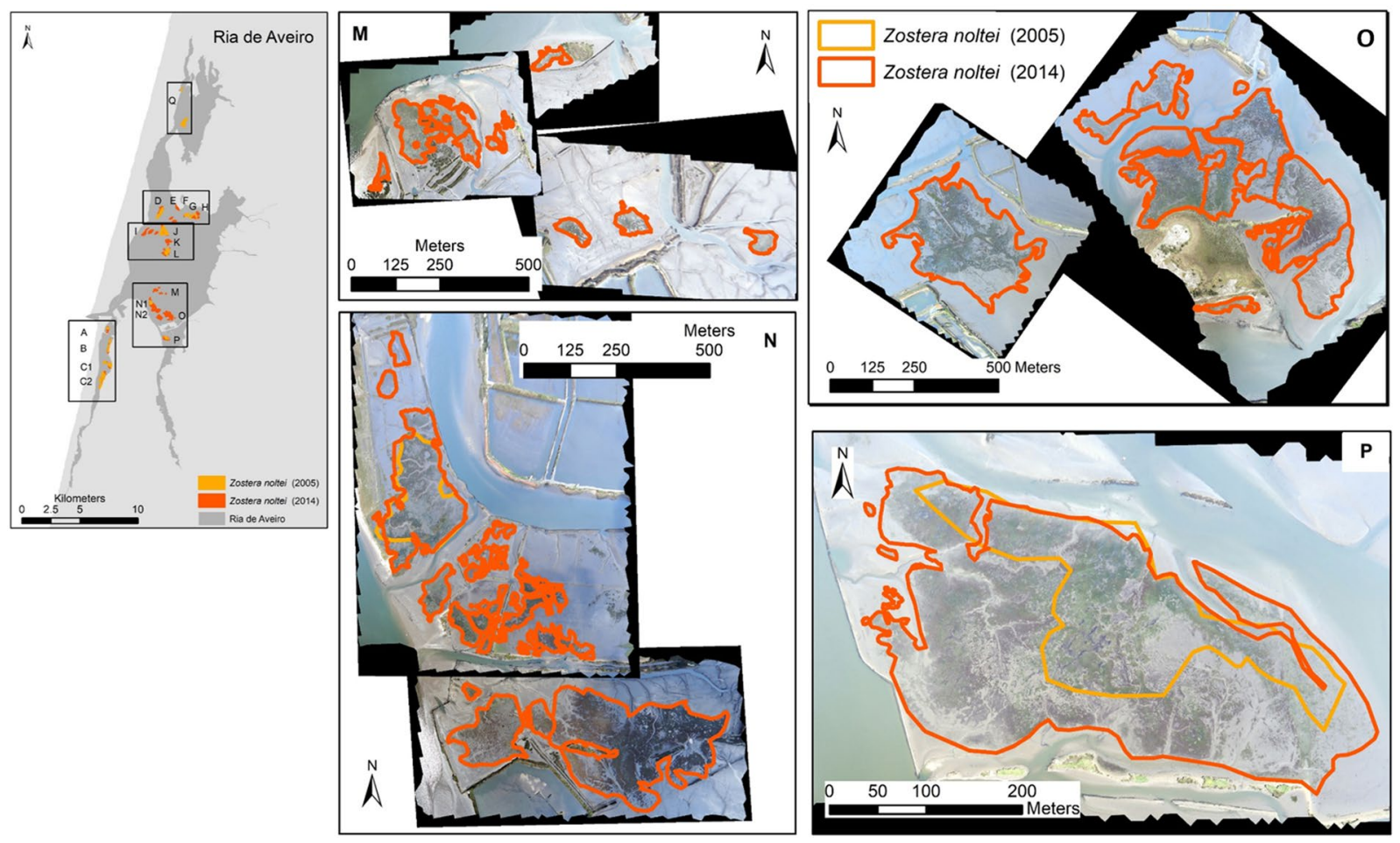

Figure 4. Zostera noltei spatial distribution at Ria de Aveiro in 2003-2005 (light orange) and in 2013/2014 (dark orange/red). Boxes aside the map show the aerial images acquired (UAV) at each area and the seagrass distribution and extent at each survey date. Areas $\mathrm{N}$ and $\mathrm{P}$ correspond to areas surveyed and mapped both in 2003-2005 and 2014; M and O were mapped only in 2014. Map generated with ArcGIS 10 (http://www.esri.com/ software/arcgis). Aerial photograph mosaic performed using Agisoft PhotoScan (https://www.agisoft.com/).

The area of seagrass meadows recorded at the Ovar channel in 2003-2005 (82 ha) was about twice the area recorded by Cunha et al..$^{28}$ in 2010 ( $43 \mathrm{ha}$ ). However, the exact locations of the areas surveyed by Cunha et al. ${ }^{28}$ were not provided, hindering their comparison. Overall, the total area of seagrass meadows surveyed in 2014 (226 ha) corresponded to the minimum Z. noltei extent recorded at Ria de Aveiro. In Mira channel, Z. noltei extent in $2008(13 \mathrm{ha})^{28}$ was lower than that recorded in the 2003-2005 survey included in the present study, suggesting there might have been episodes of temporal (and spatial) changes and fluctuations of $Z$. noltei meadows over the analysed period (Fig. 8). Overall, there was an increase in the areal extent of the $Z$. nolte $i$ meadows mapped in both periods, and newly colonised areas were observed ( $M, N$, and $O$ in the maps displayed in Figs 1 to 3). In addition, most of the meadows mapped in 2005 remained constant or showed an increased areal extents in the 2014 assessment.

Seagrass extent and coverage fluctuations correspond to either fragmentation or recovery of these habitats, which in turn depend on many physical and environmental changes occurring in the system. Increased current speed, loss of fine sediments due to erosion, nutrient loss, and sand burial were pointed out as the main causes for $Z$. noltei decline in Ria de Aveiro in the last decades of the $20^{\text {th }}$ century ${ }^{31}$. Accordingly, sediment resuspension and higher turbidity contributed to the decrease of $Z$. noltei distribution in the Ovar channel from 1984 to $2003^{32}$. Hydrodynamics, current velocities ${ }^{39}$, sediment stability ${ }^{25,40,41}$, bioturbation ${ }^{42}$, and sedimentation processes ${ }^{43}$ are $^{2}$ known to influence seagrass stability.

The most relevant events and changes occurring in Ria de Aveiro coastal lagoon over the last two centuries are summarized in Fig. S2 (supplementary information). These changes are mainly due to human intervention and activities, which led to interrelated effects, and includes modifications of the system hydrodynamics and tidal prism, salinity, and sedimentary and morphological features (please see references in Fig. S2, supplementary information). These pressures that led to the seagrass decline might have been reduced in Ria de Aveiro and the seagrass meadows were able to recover and to compensate the former decline. In fact, the last large dredging operations performed in Ria de Aveiro, involving important areas and affecting the whole system, occurred about 20 years ago (1996-1998) (Fig. S2, supplementary information).

The present study supports that between 2003-2005 and 2013-2014 seagrass meadows showed signs of recovery and resilience after multiple interacting environmental pressures. Although different feedback mechanisms (including seagrass, biotic, and abiotic variables) might be involved in such recovery and resilience signs, it is difficult to address whether a real stable alternative state is achieved by these meadows as the result of feedback mechanisms ${ }^{4}$. The importance of multiple interacting feedback mechanisms on the structure and functioning of seagrass meadows is evident and, according to Maxwell et al. ${ }^{44}$, seagrass conservation and recovery management plans might be developed after evaluating and understanding how these meadows are stabilized or disturbed by 

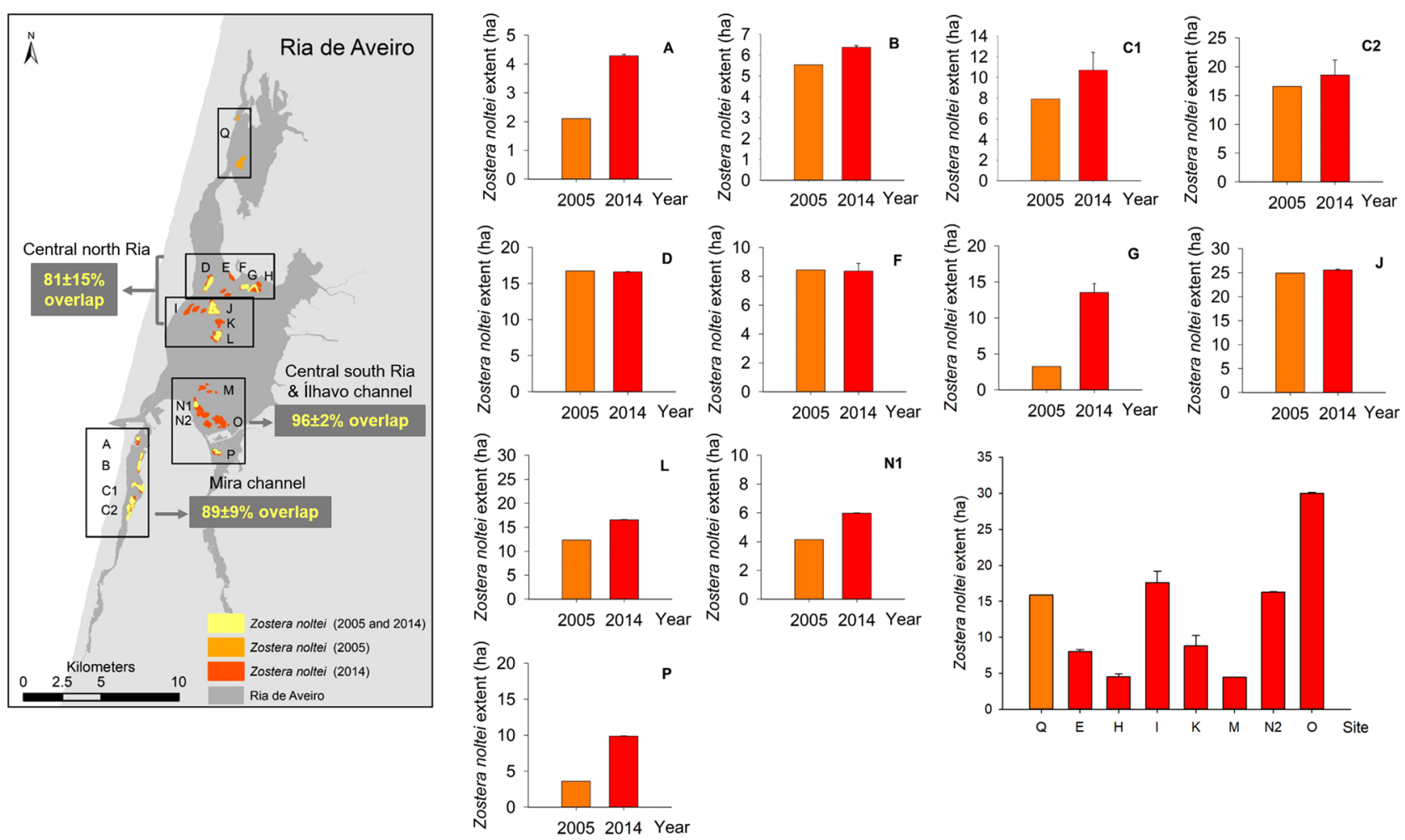

Figure 5. Zostera noltei extent (ha) at Ria de Aveiro. Data (mean $\pm \mathrm{SD})$ are shown for the surveyed areas in 2005 (light orange) and 2014 (dark orange/red), namely areas A, B, C1, C2, D, F, G, J, L, N1 and P. The meadows overlapped areas (from 2005 and 2014) are shown (yellow) and the mean overlap percentage at each Ria region is indicated in the map. The graph in the lower-right corner shows the Z. noltei extent for areas surveyed in 2005 only (area Q) and in 2014 only (areas E, H, I, K, M, N2 and O). Map generated with ArcGIS 10 (http://www.esri. com/software/arcgis). Aerial photograph mosaic performed using Agisoft PhotoScan (https://www.agisoft.com/).

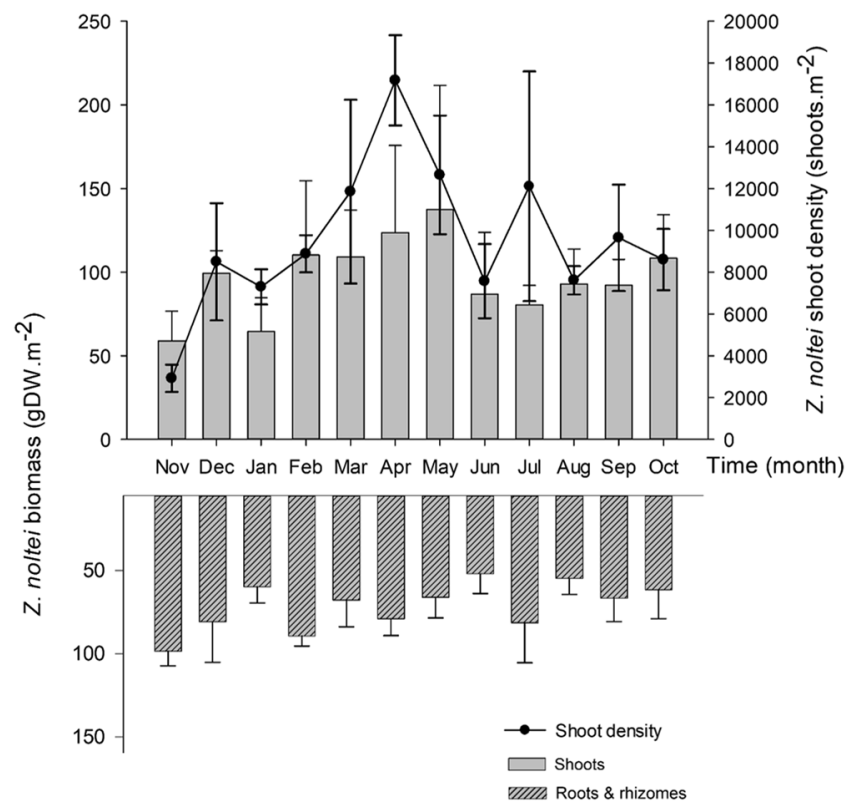

Figure 6. Zostera noltei biomass of shoots and roots \& rhizomes (A) and shoot density (B), thoughout a year, at site $\mathrm{M}$ (Mira channel). Mean values $(\mathrm{N}=5)$ and standard deviation (SD) are shown.

these feedback mechanisms, therefore increasing seagrass resilience to environmental pressures. It is known that the recovery trajectory of seagrass ecosystems after disturbance depends on the degree of the disturbance and on the resilience of the seagrasses, which in turn depend on the relative timescales of the disturbance, resistance, 


\begin{tabular}{|c|c|c|c|c|}
\hline \multirow[b]{2}{*}{ Time (month) } & \multicolumn{2}{|c|}{ Z. noltei $\mathrm{C}_{\text {org }}$ stock $\left(\mathrm{g} \mathrm{C} \mathrm{m}^{-2}\right)$} & \multirow{2}{*}{$\begin{array}{l}\text { Sediment } \mathrm{C}_{\text {org }} \\
\text { stock }\left(\mathrm{g} \mathrm{C} \mathrm{m}^{-2}\right. \\
10 \mathrm{~cm} \text { depth) }\end{array}$} & \multirow{2}{*}{$\begin{array}{l}\text { Total } \mathrm{C}_{\text {org }} \text { stock in } \\
\text { Z. noltei meadow } \\
\left(\mathrm{g} \mathrm{C} \mathrm{m}^{-2} ; 10 \mathrm{~cm}\right. \\
\text { depth) }\end{array}$} \\
\hline & Shoots & \begin{tabular}{|l} 
Roots \& \\
rhizomes
\end{tabular} & & \\
\hline Nov.12 & $23.5 \pm 7.0$ & $35.6 \pm 3.2$ & $147.3 \pm 8.7$ & $170.8 \pm 11.2$ \\
\hline Dec. 12 & $39.1 \pm 5.3$ & $29.2 \pm 8.8$ & $156.7 \pm 10.9$ & $195.8 \pm 12.1$ \\
\hline Jan.13 & $25.3 \pm 7.9$ & $21.1 \pm 3.4$ & $169.1 \pm 11.3$ & $194.4 \pm 13.8$ \\
\hline Feb.13 & $43.8 \pm 17.6$ & $31.6 \pm 2.1$ & $169.2 \pm 5.9$ & $213.0 \pm 18.6$ \\
\hline Mar.13 & $40.6 \pm 10.4$ & $24.9 \pm 5.9$ & $189.0 \pm 6.2$ & $229.6 \pm 12.1$ \\
\hline Apr.13 & $49.8 \pm 20.9$ & $28.1 \pm 3.6$ & $168.1 \pm 9.9$ & $217.8 \pm 23.1$ \\
\hline May.13 & $52.4 \pm 28.2$ & $22.6 \pm 4.3$ & $157.4 \pm 5.5$ & $209.9 \pm 28.7$ \\
\hline Jun.13 & $33.2 \pm 14.1$ & $17.6 \pm 4.0$ & $158.7 \pm 9.3$ & $191.9 \pm 16.9$ \\
\hline Jul.13 & $31.4 \pm 4.5$ & $27.3 \pm 8.0$ & $150.8 \pm 4.9$ & $182.2 \pm 6.7$ \\
\hline Aug.13 & $34.4 \pm 7.7$ & $18.4 \pm 3.3$ & $163.3 \pm 5.3$ & $197.7 \pm 9.4$ \\
\hline Sep.13 & $35.7 \pm 5.9$ & $23.0 \pm 4.9$ & $167.2 \pm 9.8$ & $202.9 \pm 11.5$ \\
\hline Oct.13 & $41.4 \pm 9.9$ & $22.0 \pm 6.2$ & $156.7 \pm 5.2$ & $198.1 \pm 11.2$ \\
\hline $\mathrm{C}_{\text {org }}$ stock $($ mean $\pm S D)$ & $37.6 \pm 8.8$ & $25.1 \pm 5.4$ & $162.8 \pm 10.9$ & $200.3 \pm 15.8$ \\
\hline
\end{tabular}

Table 1. $\mathrm{C}_{\text {org }}$ stock of Zostera noltei and sediment $\left(0-10 \mathrm{~cm}\right.$ depth; mean $\pm \mathrm{SD}$, except for total $\mathrm{C}_{\text {org }}$ stock, wherein mean \pm error propagation is shown), over a year (at each sampling date) at site M (Mira channel, Ria de Aveiro, Portugal), recorded in a meadow with $100 \%$ coverage.

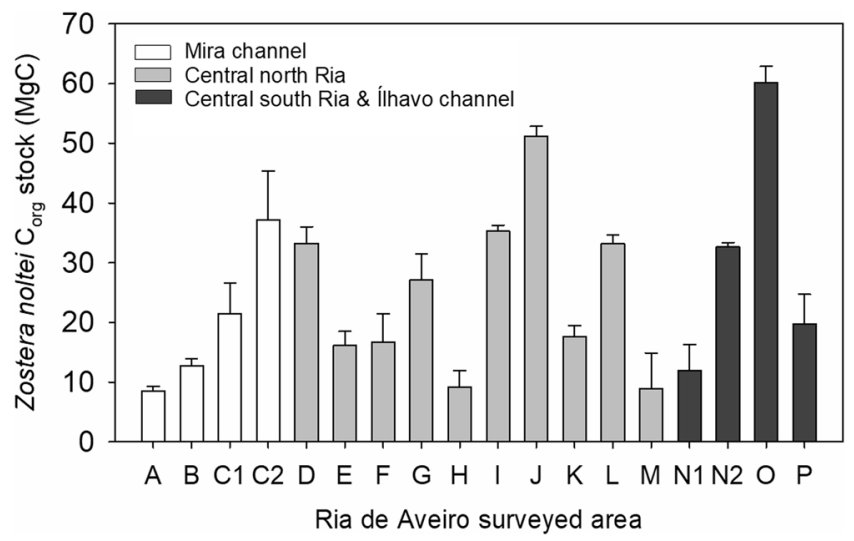

Figure 7. $\mathrm{C}_{\text {org }}$ stock in Z. noltei meadows (seagrass + sediment) at Ria de Aveiro surveyed areas in 2014 (A to $\mathrm{L})$, considering a the maximum $(100 \%)$ relative cover and $10 \mathrm{~cm}$ sediment depth. Mean $\mathrm{C}_{\text {org }}$ values \pm associated error propagation are shown in the graph.

and recovery processes ${ }^{45}$. These processes are affected by the state and characteristics of the seagrass population, which are tightly dependent on the environmental conditions, feedback mechanisms, scale of degradation, and disturbance history ${ }^{45}$.

There are relevant examples of seagrass meadows recovery in Portuguese (e.g. Mondego estuary ${ }^{25}$ and Ria Formosa ${ }^{43}$ ) and international systems (e.g. Bay of Santander, Spain ${ }^{46}$, Bourgneuf Bay, France ${ }^{47}$ ). In addition, a very recent work shows that, in contrast with global estimations, seagrass decline is not generalised in Europe and a recent slowdown and reversal of declining trends have been occurring in some European systems ${ }^{48}$. In the case of Ria de Aveiro, this recovery trend needs special attention because a relevant dredging intervention is foreseen in the system management plan for the near future $(2018 / 2019)^{49}$. While some meadows are likely to be negatively affected by sediment dredging and deposition, other areas might become favourable for $Z$. noltei establishment, growth, and expansion. Auspicious areas for seagrasses colonisation depend mainly on their exposure to tidal action, elevation, tidal amplitude, tidal prism, and sediment properties. The interaction of these multiple variables, which will also be affected in a mid-long term scale by sea level rise, will therefore determine the areas that are more likely to be colonised by seagrasses.

Concerning Z. noltei biomass, the annual mean for the Mira channel $\left(169 \pm 25 \mathrm{~g} \mathrm{DW} \mathrm{m}^{-2}\right)$ obtained here is similar to that previously recorded for Ria de Aveiro, namely $154 \pm 142 \mathrm{~g} \mathrm{DW} \mathrm{m}^{-2}(2003)^{32}, 110 \pm 50 \mathrm{~g}$ AFDW $\mathrm{m}^{-2}(2002-2004)^{31}$ and $91 \pm 42 \mathrm{DW} \mathrm{m}^{-2}$ (shoots $^{38}$ ) and $46 \pm 15 \mathrm{~g} \mathrm{DW} \mathrm{m}^{-238}$ (Fig. 6), and it is in accordance with that obtained for Palmones River (Spain) ${ }^{50}$ and Ria Formosa (Portugal) ${ }^{51,52}$. The shoot density in Mira channel (annual mean: $9567 \pm 4178$ shoots $\mathrm{m}^{-2}$ ) was higher than in other systems, particularly Ria Formosa (southern Portugal), wherein density varied amongst undisturbed and physically disturbed meadows by clam harvesting ${ }^{51}$. Changes in Z. noltei shoot density after a disturbance event (physical impact by artificial opening of an inlet) were also observed by Peralta et al..$^{52}$. Therefore, different feedback mechanisms may affect the $Z$. noltei morphological response to disturbances. 


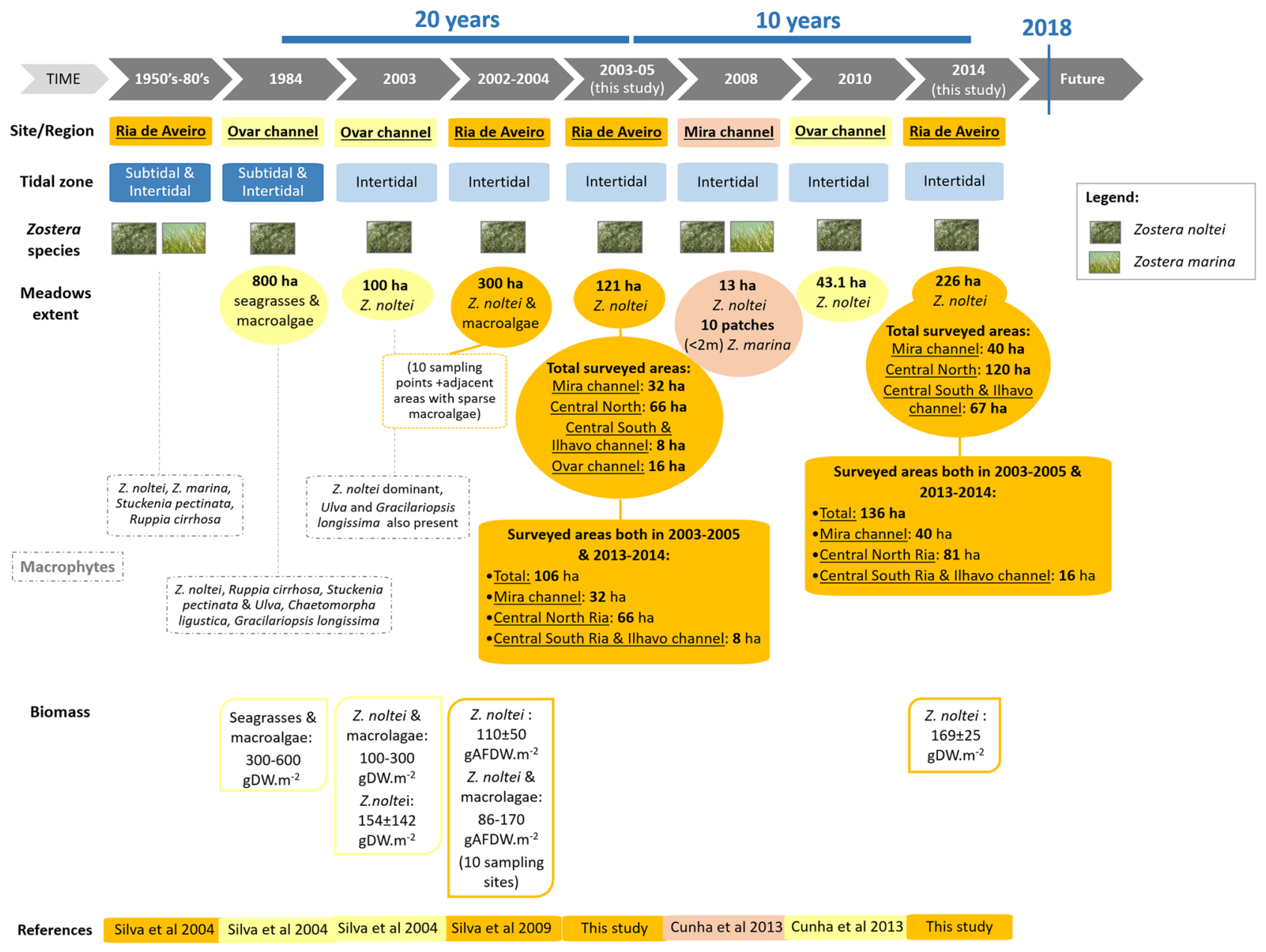

Figure 8. Seagrass meadows spatio-temporal changes at Ria de Aveiro from the 1950's to 2014. Columns show the data at each surveyed time-range and the corresponding reference. For each site/region, different colours correspond to different surveyed areas of the lagoon (orange: Ria de Aveiro; light yellow: Ovar channel; light orange/pink: Mira channel), and corresponding meadows' extent, macrophyte' species and biomass data are indicated. Concerning tidal zone, dark blue refers to subtidal and intertidal zones, while light blue refers to intertidal zone only. References: Silva et al. ${ }^{33}$; Silva et al..$^{32}$; This study; Cunha et al. ${ }^{29}$.

The Z. noltei $\mathrm{C}$ content recorded in the present study (annual mean of $39 \pm 1 \%$ for shoots and $35 \pm 1 \%$ for roots and rhizomes) was slightly higher, but in the same range as the data recently obtained by Sousa et al. ${ }^{38}$. In Ria Formosa, the C content of Z. noltei shoots was slightly higher (43-44\%) $)^{51}$ than in Ria de Aveiro, while in the Palmones River it ranged from $30-40 \%$ in the shoots and from $25-40 \%$ in the roots and rhizomes.

Blue $\mathrm{C}$ stock $\left(\mathrm{C}_{\text {org }}\right)$ in the $Z$. noltei meadows of Ria de Aveiro directly depends on the seagrass meadows condition, which is affected by the system stability, in turn influencing the biomass and Blue $\mathrm{C}$ stored in both the seagrass biomass and in the sediment. In 2013-2014, Z. noltei biomass and $\mathrm{C}_{\text {org }}$ content in the seagrass and sediment were monitored monthly over a year to examine seasonal variation. As mentioned before, sampling was performed in a well-established meadow with $100 \% \mathrm{Z}$. noltei relative coverage. The maximum Blue $\mathrm{C}$ stored in the Ria de Aveiro seagrass meadows was calculated considering the best available information. In 2005, the maximum relative cover of $Z$. noltei (100\%) was considered, while in 2014 Blue C stock was calculated for the $50-100 \%$ range of $Z$. noltei cover, rather than for a specific value. This range accounted for the potential habitat fragmentation in some of the mapped and monitored meadows and for the low relative cover in certain $Z$. noltei meadows. Overall, in 2005, the maximum Blue C stored in Ria de Aveiro Z. noltei meadows was $243 \mathrm{Mg}$ C, while in 2014 these meadows stored and sequestered 227 (50\% cover) to $453 \mathrm{Mg} \mathrm{C}$ (maximum, 100\% cover). However, it must be taken into account that a $50 \%$ cover meadow that used to be a well-established area (with $100 \%$ cover) will have an higher meaning for Blue $\mathrm{C}$ storage than a $50 \%$ cover meadow corresponding to a new colonised area that is still increasing its relative cover. Thus, the $\mathrm{C}$ stored in a former $100 \%$ cover meadow is not expected to be completely lost when a shift to $50 \%$ cover occurs, i.e., part of the stored $\mathrm{C}$ will still remain in the sediment.

The total $\mathrm{C}_{\text {org }}$ stock recorded, corresponding to the mean $\mathrm{C}_{\text {org }}$ stock on a per area basis, $\left(200.3 \pm 15.8 \mathrm{~g} \mathrm{C} \mathrm{m}^{-2}\right.$; $10 \mathrm{~cm}$ depth; sediment and seagrass) was similar to the minimum value obtained for the sediment $\mathrm{C}_{\text {org }}$ stock recorded in three subarctic Zostera marina meadows, ranging from $197 \mathrm{~g} \mathrm{C} \mathrm{m}^{-2}$ to $595 \mathrm{~g} \mathrm{C} \mathrm{m}^{-2}$ (top $10 \mathrm{~cm}$ ), located in three fjords of the Godthåbsfjordsystem (West Greenland) ${ }^{6}$. In the Red Sea seagrasses of Abu Dhabi, the 
sediment $\mathrm{C}_{\text {org }}$ stock of Halodule uninervis, Halophila ovalis, and Halophila stipulacea meadows ranged from 0.2 to $10.9 \mathrm{~kg} \mathrm{C}_{\text {org }} \mathrm{m}^{-253}$ (1 $\mathrm{m}$ top layer), which corresponds to $20-1090 \mathrm{~g} \mathrm{C}_{\text {org }} \mathrm{m}^{-2}$ in the top 10-cm layer (although bearing in mind the limitations of this correspondence). The sediment $\mathrm{C}_{\text {org }}$ obtained for Z. noltei in Ria de Aveiro was lower than that estimated for other seagrass species (Thalassia hemprichii, Enhalus acoroides, Halophila stipulacea, Thalassodendrum ciliatum, and Halodule uninervis) in the Red Sea, Saudi Arabia, wherein an average of $3.4 \pm 0.3 \mathrm{~kg} \mathrm{C}_{\text {org }} \mathrm{m}^{-2}$ in the top $1 \mathrm{~m}$ sediment layer was recorded, corresponding to $340 \mathrm{~g} \mathrm{C}_{\text {org }} \mathrm{m}^{-2}$ in the top $10 \mathrm{~cm}$ layer ${ }^{7}$. In Shark Bay (western Australia), an average of $12.8 \mathrm{~kg} \mathrm{C}_{\text {org }} \mathrm{m}^{-2}$ was obtained for the top $1 \mathrm{~m}$ sediment layer ( $1.28 \mathrm{~kg} \mathrm{C}_{\text {org }} \mathrm{m}^{-2}$ in the top $10 \mathrm{~cm}$ sediment layer, through direct conversion), and $50 \%$ of the sediment $\mathrm{C}_{\text {org }}$ stocks assessed ranged from $9.2-16.1 \mathrm{~kg} \mathrm{C}_{\text {org }} \mathrm{m}^{-2}\left(0.92-1.61 \mathrm{~kg} \mathrm{C}_{\text {org }} \mathrm{m}^{-2}\right.$ in the top 10-cm sediment layer, through direct conversion $)^{15}$. Thus, the results of the present study highlight the importance of seagrass meadows for storing Blue $\mathrm{C}$ and reducing the $\mathrm{CO}_{2}$ concentration in the atmosphere, which in turn contributes to climate regulation and other paramount ecosystem services including habitat provisioning, sediment stabilization, and water quality improvement. Therefore, it is crucial to preserve seagrass meadow ecosystems and to promote their recovery, as they contribute to the health of the entire ecosystem. The 2014 seagrass map obtained for Ria de Aveiro will be further improved regarding image resolution and by using multispectral imagery, to better assess the presence of seagrasses and estimate the relative coverage of the meadows. This will enhance seagrass mapping accuracy, allowing a better understanding of the ecological and physical changes occurring at this coastal lagoon system, particularly under the foreseen management interventions.

\section{Conclusions}

Previous relevant work on the characterization and mapping of seagrass meadows was performed at Ria de Aveiro. However, this is the first study comprising extensive seagrass meadows mapping and Blue C stock assessment at this coastal lagoon, establishing a reference for seagrass meadows location, extent, and Blue $\mathrm{C}$ stock. Overall, Ria de Aveiro Z. noltei intertidal meadows seem to contradict the global decline trend, and corroborate a recent declining trend reversal observed in Europe, thereby contributing to the effective increase of the Blue C stock, and ultimately, to climate regulation and ecosystem health. This recovery over the 2003-2005 to 2013-2014 period might be related to a natural adjustment to past human interventions in the system, namely large-scale dredging activities, combined with a more accurate assessment of seagrass meadow areas due to the use of the UAV. The present study establishes a new baseline to assess the impact of the major dredging activities that are foreseen in the management plan of Ria de Aveiro, which can again endanger the recovery trend observed for $Z$. noltei intertidal meadows.

\section{Data Availability}

The datasets generated and/or analysed during the current study are available on reasonable request.

\section{References}

1. McLeod, E. et al. A blueprint for blue carbon: Toward an improved understanding of the role of vegetated coastal habitats in sequestering $\mathrm{CO}_{2}$. Frontiers in Ecology and the Environment 9, 552-560 (2011).

2. Beaumont, N. J., Jones, L., Garbutt, A., Hansom, J. D. \& Toberman, M. The value of carbon sequestration and storage in coastal habitats. Estuar. Coast. Shelf Sci. 137, 32-40 (2014).

3. Fourqurean, J. W. et al. Seagrass ecosystems as a globally significant carbon stock. Nat. Geosci. 5, 505-509 (2012).

4. Herr, D. Pidgeon, E. \& Laffoley, D. Blue Carbon Policy Framework: Based on the discussion of the International Blue Carbon Policy Working Group (2011).

5. IPCC. Climate Change 2014: Synthesis Report. Contribution of Working Groups I, II and III to the Fifth Assessment Report of the Intergovernmental Panel on Climate Change. Core Writing Team, R.K. Pachauri and L.A. Meyer (IPCC, 2014).

6. Marbà, N., Krause-Jensen, D., Masqué, P. \& Duarte, C. M. Expanding Greenland seagrass meadows contribute new sediment carbon sinks. Sci. Rep. 8, 14024 (2018).

7. Serrano, O., Almahasheer, H., Duarte, C. M. \& Irigoien, X. Carbon stocks and accumulation rates in Red Sea seagrass meadows. Sci. Rep. 8, 15037 (2018).

8. Hyndes, G. A. et al. Mechanisms and ecological role of carbon transfer within coastal seascapes. Biol. Rev. 89, 232-254 (2014).

9. Duarte, C. M., Middelburg, J. J. \& Caraco, N. Major role of marine vegetation on the oceanic carbon cycle. Biogeosciences Discuss. 1, 659-679 (2005).

10. Valdemarsen, T., Quintana, C. O., Kristensen, E. \& Flindt, M. R. Recovery of organic-enriched sediments through microbial degradation: Implications for eutrophic estuaries. Mar. Ecol. Prog. Ser. 503, 41-58 (2014).

11. Duarte, C. M., Losada, I. J., Hendriks, I. E., Mazarrasa, I. \& Marbà, N. The role of coastal plant communities for climate change mitigation and adaptation. Nature Climate Change 3, 961-968 (2013).

12. Howard, J. et al. Clarifying the role of coastal and marine systems in climate mitigation. Front. Ecol. Environ. 15, 42-50 (2017).

13. Orth, R. J. et al. A Global Crisis for Seagrass Ecosystems. Bioscience 56, 987-996 (2006).

14. Waycott, M. et al. Accelerating loss of seagrasses across the globe threatens coastal ecosystems. Proc. Natl. Acad. Sci. 106, 12377-12381 (2009).

15. Arias-Ortiz, A. et al. Reviews and syntheses: $210 \mathrm{~Pb}$-derived sediment and carbon accumulation rates in vegetated coastal ecosystems - Setting the record straight. Biogeosciences 15, 6791-6818 (2018).

16. Barañano, C., Fernández, E. \& Méndez, G. Clam harvesting decreases the sedimentary carbon stock of a Zostera marina meadow. Aquat. Bot. 146, 48-57 (2018).

17. Canal-Vergés, P., Petersen, J. K., Rasmussen, E. K., Erichsen, A. \& Flindt, M. R. Validating GIS tool to assess eelgrass potential recovery in the Limfjorden (Denmark). Ecological Modelling 338, 135-148 (2016).

18. Pendleton, L. et al. Estimating Global 'Blue Carbon' Emissions from Conversion and Degradation of Vegetated Coastal Ecosystems. PLoS One 7, (2012).

19. Christensen, P. B., Rysgaard, S., Sloth, N. P., Dalsgaard, T. \& Schwærter, S. Sediment mineralization, nutrient fluxes, denitrification and dissimilatory nitrate reduction to ammonium in an estuarine fjord with sea cage trout farms. Aquat. Microb. Ecol. 21, 73-84 (2000).

20. Atwood, T. B. et al. Predators help protect carbon stocks in blue carbon ecosystems. Nat. Clim. Chang. 5, 1038-1045 (2015).

21. Valdemarsen, T., Wendelboe, K., Egelund, J. T., Kristensen, E. \& Flindt, M. R. Burial of seeds and seedlings by the lugworm Arenicola marina hampers eelgrass (Zostera marina) recovery. J. Exp. Mar. Bio. Ecol. 410, 45-52 (2011). 
22. Wendelboe, K., Egelund, J. T., Flindt, M. R. \& Valdemarsen, T. Impact of lugworms (Arenicola marina) on mobilization and transport of fine particles and organic matter in marine sediments. J. Sea Res. 76, 31-38 (2013).

23. Duarte, C. M. The future of seagrass meadows. Environ. Conserv. 29, 192-206 (2002).

24. Lewis, M. A. \& Devereux, R. Nonnutrient anthropogenic chemicals in seagrass ecosystems: Fate and effects. Environmental Toxicology and Chemistry 28, 644-661 (2009).

25. Lillebø, A. I. et al. In Treatise on Estuarine and Coastal Science 10, 151-164 (2011).

26. Short, F. T. \& Wyllie-Echeverria, S. Natural and human-induced disturbance of seagrasses. Environ. Conserv. 23, 17 (1996).

27. Azevedo, A., Sousa, A. I., Lencart e Silva, J. D., Dias, J. M. \& Lillebø, A. I. Application of the generic DPSIR framework to seagrass communities of Ria de Aveiro: a better understanding of this coastal lagoon. J. Coast. Res. 65, 19-24 (2013).

28. Cunha, A. H., Assis, J. F. \& Serrão, E. A. Seagrasses in Portugal: A most endangered marine habitat. Aquat. Bot. 104, 193-203 (2013).

29. Duck, R. W. \& da Silva, J. F. Coastal lagoons and their evolution: A hydromorphological perspective. Estuar. Coast. Shelf Sci. 110, 2-14 (2012).

30. Silva, J. F. \& Duck, R. W. Historical changes of bottom topography and tidal amplitude in the Ria de Aveiro, Portugal-trends for future evolution. Clim. Res. 18, 17-24 (2001).

31. Silva, J. F., Duck, R. W. \& Catarino, J. B. Nutrient retention in the sediments and the submerged aquatic vegetation of the coastal lagoon of the Ria de Aveiro, Portugal. J. Sea Res. 62, 276-285 (2009).

32. Silva, J. F., Duck, R. W. \& Catarino, J. B. Seagrasses and sediment response to changing physical forcing in a coastal lagoon. Hydrol. Earth Syst. Sci. 8, 151-159 (2004).

33. Silva, J. F. \& Duck, R. W. Identification of the effects of recent tidal regime changes in intertidal areas of the Ria de Aveiro, Portugal, using airborne and surface observations. Geophys. Res. Abstr. 9, (2007).

34. Silva, J. F., Duck, R. W. \& Changing, C. J. Changing use of the estuarine system of the Ria de Aveiro, Portugal, and resultant impact on tidal flat sediments. Mater. Geoenvironment 52, 111-114 (2005).

35. Santos, R. \& Duarte, P. Marine Plant Harvest in Portugal. J. Appl. Phycol. 3, 11-18 (1991).

36. Howard, J., Hoyt, S., Isensee, K., Pidgeon, E., Telszewski, M. (eds) Coastal Blue Carbon: Methods for assessing carbon stocks and emissions factors in mangroves, tidal salt marshes, and seagrass meadows. Conservation International, Intergovernmental Oceanographic Commission of UNESCO, International Union for Conservation of Nature. Arlington, Virginia, USA (2014).

37. Phillips, S. C., Johnson, J. E., Miranda, E. \& Disenhof, C. Improving CHN measurements in carbonate-rich marine sediments. Limnol. Oceanogr. Methods 9, 194-203 (2011).

38. Sousa, A. I. et al. Effect of spatio-temporal shifts in salinity combined with other environmental variables on the ecological processes provided by Zostera noltei meadows. Sci. Rep. (2017).

39. Schanz, A. \& Asmus, H. Impact of hydrodynamic on developement and morphology of intertidal seagrasses in the Wadden Sea. Mar. Ecol. Prog. Ser. 261, 123-134 (2003).

40. Lundkvist, M., Gangelhof, U., Lunding, J. \& Flindt, M. R. Production and fate of extracellular polymeric substances produced by benthic diatoms and bacteria: A laboratory study. Estuar. Coast. Shelf Sci. 75, 337-346 (2007).

41. Marba, N. \& Duarte, C. M. Coupling of Seagrass (Cymodocea Nodosa) Patch Dynamics to Subaqueous dune Migration. J. Ecol. 83, 381-389 (1995).

42. Kristensen, E. et al. Influence of benthic macroinvertebrates on the erodability of estuarine cohesive sediments: Density- and biomass-specific responses. Estuar. Coast. Shelf Sci. 134, 80-87 (2013).

43. Cunha, A. H., Santos, R. P., Gaspar, A. P. \& Bairros, M. F. Seagrass landscape-scale changes in response to disturbance created by the dynamics of barrier-islands: A case study from Ria Formosa (Southern Portugal). Estuar. Coast. Shelf Sci. 64, 636-644 (2005).

44. Maxwell, P. S. et al. The fundamental role of ecological feedback mechanisms for the adaptive management of seagrass ecosystems - a review. Biol. Rev. 92, 1521-1538 (2017).

45. O'Brien, K. R. et al. Seagrass ecosystem trajectory depends on the relative timescales of resistance, recovery and disturbance. Mar. Poll. Bull 134, 166-176 (2018).

46. Calleja, F., Galván, C., Silió-Calzada, A., Juanes, J. A. \& Ondiviela, B. Long-term analysis of Zostera noltei: A retrospective approach for understanding seagrasses' dynamics. Mar. Environ. Res. 130, 93-105 (2017).

47. Barillé, L., Robin, M., Harin, N., Bargain, A. \& Launeau, P. Increase in seagrass distribution at Bourgneuf Bay (France) detected by spatial remote sensing. Aquat. Bot. 92, 185-194 (2010).

48. de los Santos, C. B. et al. Recent trend reversal for declining European seagrass meadows. Nat. Commun. 10, 3356 (2019).

49. POLIS. Projeto de execução de transposição de sedimentos para otimização do equilíbrio hidrodinâmico na Ria de Aveiro - Canal de Mira - Relatório de conformidade ambiental do projeto de execução (2017).

50. Pérez-Lloréns, J. L. \& Niell, F. X. Seasonal dynamics of biomass and nutrient content in the intertidal seagrass Zostera noltii Hornem. from Palmones River estuary, Spain. Aquat. Bot. 46, 49-66 (1993).

51. Cabaço, S., Machás, R. \& Santos, R. Individual and population plasticity of the seagrass Zostera noltii along a vertical intertidal gradient. Estuar. Coast. Shelf Sci. 82, 301-308 (2009).

52. Peralta, G., Brun, F. G., Hernández, I., Vergara, J. J. \& Pérez-Lloréns, J. L. Morphometric variations as acclimation mechanisms in Zostera noltii beds. Estuar. Coast. Shelf Sci. 64, 347-356 (2005).

53. Campbell, J. E., Lacey, E. A., Decker, R. A., Crooks, S. \& Fourqurean, J. W. Carbon Storage in Seagrass Beds of Abu Dhabi, United Arab Emirates. Estuaries and Coasts 38, 242-251 (2015).

\section{Acknowledgements}

Thanks are due, for the financial support to CESAM (UID/AMB/50017/2019), to FCT/MCTES through national funds. The European Commission, under the 7th Framework Programme, supported this study through the collaborative research project LAGOONS (contract no. 283157). This work is funded by the project PORBIOTA - Portuguese E-Infrastructure for Information and Research on Biodiversity (POCI-01-0145-FEDER-022127), supported by Operational Thematic Program for Competitiveness and Internationalization (POCI), under the PORTUGAL 2020 Partnership Agreement, through the European Regional Development Fund (FEDER).; and the project BIOPRADARIA - Restoration, management \& conservation of biodiversity \& biological resources associated with Ria de Aveiro seagrass ecosystems (MAR-01.04.02-FEAMP-0020), funded by "Programa Operacional MAR2020", EMFF - European Maritime and Fisheries Fund, European Union and Portugal 2020. The Post-Doc grants SFRH/BPD/79537/2011, SFRH/BPD/107823/2015 (A.I. Sousa) and the PhD grant SFRH/ $\mathrm{BD} / 84613 / 2012$ (A. Azevedo) supported by FCT are also acknowledged. AI Sousa was also funded by national funds through the FCT- Foundation for Science and Technology, I.P., under the project CEECIND/00962/2017. We thank Mogens R. Flindt (SDU - Southern Denmark University, Denmark) for the valuable comments on the manuscript and for the CHN analyses, Katrine Clement Kirkegaard (SDU, Denmark) for running the CHN analyses, and Nuno Rodrigues (University of Aveiro, Portugal) for his contribution in the aerial images processing. 


\section{Author Contributions}

A.I.S. and A.I.L. conceived and designed the study. A.I.S., J.F.S., A.A. carried out the field work. A.I.S. and A.A. carried out the laboratory work. A.I.S. analysed the data. A.I.L. contributed with financial support. A.I.S. led the writing of the manuscript with important contributions from A.I.L. All authors contributed critically to the manuscript draft and gave final approval for publication.

\section{Additional Information}

Supplementary information accompanies this paper at https://doi.org/10.1038/s41598-019-50425-4.

Competing Interests: The authors declare no competing interests.

Publisher's note Springer Nature remains neutral with regard to jurisdictional claims in published maps and institutional affiliations.

(c) (i) Open Access This article is licensed under a Creative Commons Attribution 4.0 International License, which permits use, sharing, adaptation, distribution and reproduction in any medium or format, as long as you give appropriate credit to the original author(s) and the source, provide a link to the Creative Commons license, and indicate if changes were made. The images or other third party material in this article are included in the article's Creative Commons license, unless indicated otherwise in a credit line to the material. If material is not included in the article's Creative Commons license and your intended use is not permitted by statutory regulation or exceeds the permitted use, you will need to obtain permission directly from the copyright holder. To view a copy of this license, visit http://creativecommons.org/licenses/by/4.0/.

(C) The Author(s) 2019 